\title{
橋義歯ポンティック下粘膜の組織反応
}

一ポンティック基底面の接触条件の違いによる影響一

清野 和夫 佐瀬 達男 伊藤 邦彦

石川 成美 小田島正博 石橋 寛二

\section{Tissue Reactions of the Mucosa due to Different Types of Contacts with Fixed Partial Denture Pontics}

\author{
Kazuo Seino, Tatsuo Sase, Kunihiko Itoh, Shigemi Ishikawa, \\ Masahiro Odashima and Kanji Ishibashi
}

\section{I. 緒 言}

粘膜接触型ポンティックは審美性，装着感に優れ，そ の適応範囲が広いことから日常の臨床に応用される覑度 が高い．しかし，ポンティック基底面を歯槽堤粘膜に接 触させる関係上，ポンティック下粘膜を健康に維持する ためには簃しい条件が要求される. そのため, 生物学的 観点から，歯槽堤粘膜との接触関係をいかに設定するか が重要な課題となる．歯槽堤粘膜との接触様式，特に， 粘膜との接触強さがプラークの付着状況に関与すること が指摘され，基底面に付着するプラークから周囲組織を 護る立場で検討されてきた. しかし，接触程度とポンテ ィック下粘膜の組織反応との関連については詳細に検討 されておらず，十分な解明がなされていない。

今回，ポンティック基底面と粘膜との好ましい接触関 䌽を確立するために，ポンティック基底面の接触条件の 違いがポンティック下粘膜に及ぼす影響を口腔生体顕微 鏡を用いて検討したので報告する.

岩手医科大学歯学部歯科補緅学第 2 講座 (主任: 石 橋 寞二教 授) Department of Fixed Prosthodontics, School of dentistry, Iwate Medical University (Chief : Prof. Kanji Ishibashi) 昭和 60 年 5 月 23 日受付

\section{II. 実験方法}

\section{1. 被験者}

岩手医科大学歯学部男子学生の中から，全身状態が良 好で, 下係第 1 大臼歯を欠損し, 支台歯周囲組織拉よび 歯槽堤粘膜に臨床的異常所見がなく，橋義歯の適応と考 えられた 4 名を被験者として選択した．その内訳は，年 齢が 24〜27 歳で, 抜歯後 1 12 年を経過し, その間,

橋義歯㧍よびその他の欠損補緅の既往はない.

実験を開始する前に，ポンティック基底面の清掃方法 を指導した. 最初に歯ブラシ（ライオンクーパー社製： オーラル B \# 35）を用いスクラビング法で口腔内を清掃 させ,つぎにデンタルフロス（エジュケイショナルヘル スプロダクッ社製；スーパーフロス）を用いてポンティ ック基底面を清掃するよう指導した.

\section{2. 実験装置}

通法に従い，下頡第 2 小臼歯と下顎第 2 大臼歯を支台 歯形成し, シリコン印象材 (三金工業社製 ; トシコン) で印象採得後, 作業模型を製作した. この作業模型上で, $12 \%$ 金銀パラジウム合金（而至社製；キャストウェル） を用いて全部鋳造冠を鋳造製作し，支台装置とした．ポ ンティック部は図 1 に示すように，支台装置に連結した 咬合面部と着脱可能な基底面部とから構成されている. 基底面部は陶材焼付用金合金（三金工業社製; ポーセレ ンメタル $12 \mathrm{~K}$ ) を用いて鋳造製作し, プラーク付着の経 

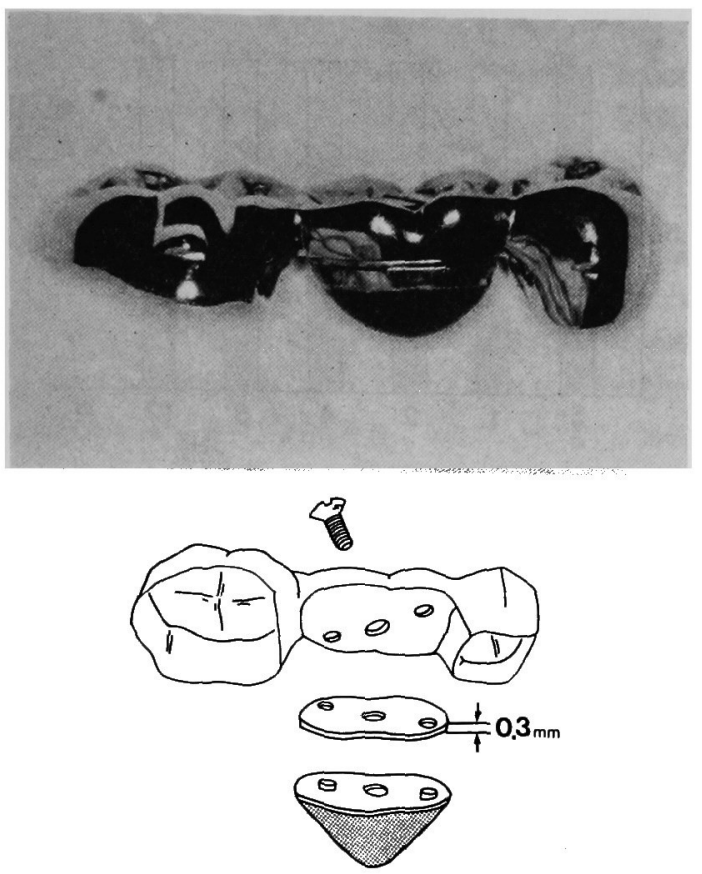

図 1 実験に用いた橋義歯(a)とその模式図(b)

時的観察を容易にするため陶材 (Vita 社製；VMK-68) にブラックスティンを混合して築盛，焼成し，笣焼きを 行った.この基底面部をスクリュー（三金工業社製；土 キスパンジョンスクリュー，609-100，609-200）で咬合 面部と連結固定できるよう設計した.

ポンティック基底面形態は楕円型とし，歯槽堤粘膜と の接触関保は非圧迫型と压迫型の 2 条件を設定した. 非 圧迫型はポンティック基底面が作業模型上の粘膜面と接 するよらに製作し，圧迫型は非圧迫型のポンティック部 に $0.3 \mathrm{~mm}$ の $12 \%$ 金銀パラジウム合金板を介在させ て 圧迫程度を設定した.

\section{3. 観察方法}

ポンティック下粘膜の観察には口腔生体 顕 微 鏡 M100 型を用い，微細な組織反応を上皮および上皮下血管 の変化としてとらえた. 生体染色は $5 \%$ エバンスブルー 水溶液と $10 \%$ トルイジンブルー水溶液による重染色 法1) で行い，染色時間は 90 秒とし，流水で 15 秒間水洗 した. 口腔生体䫓微鏡で観察された毛細血管倸蹄の形態 はつぎのように分類し2，各形態が視野内に占める割合 を百分率で表した（図 2 ).

I 型 : 倸蹄頂が脚の短いループ状, 線状, 点状を示す もの

\section{I 型へ, $\bullet$ \\ II 型 $\& \& 9$ \\ III 型 $\& \beta$}

図 2 毛細血管係蹄の分類

II 型：単純な屈曲, 交叉を示すもの

II型 : 連続した届曲，交叉を示すもの

ポンティック基底面に付着するプラークの観察は古川 らの方法) に基ゔき，ポンティック基底面が歯槽堤粘膜 と接触あるいは近接する領域を対象とした。

\section{4. 観察期間}

実験開始日に，橋義歯が支台歯汇適合していることを 確認しながら，仮着材（而至社製；テンポラリーパック） で装着した。

まず，非圧迫型ポンティックについて，1, 2, 4, 8, 12 週目の各期間に, 肉眼的観察, プラーク付着の観察, 口 腔生体顕微鏡による観察を行った。つぎに，橋義歯を撤 去し， 2 週間のインターバルをおいた後，圧迫型ポンテ ィックについて同様な観察を行った.

\section{III. 実験結果}

1. コントロール

コントロールとした橋義蒾装着前の歯槽堤粘膜は肉眼 的に健康粘膜の性状を有し, 滑めらかな曲面を呈してい た. 口腔生体顕微鏡による上皮下血管所見は線状, 点 状，ループ状を呈する I 型で $93 \%$, 屈曲, 交叉を呈する II型で 7\%を示した. 染色上皮所見では，上皮細胞はそ の多くで染色されず，染色されたものでは多角形を呈 し，淡染していた。 上皮細胞の核も淡染し，明膫に認め られないものが多かった（図 3，4）。

\section{2. 非圧迫型ポンティック}

非圧迫型ポンティック下の歯槽堤粘膜は，観察期間を 通して肉眼的に健康粘膜の性状を呈しており，歯槽堤の 形態にも変化がみられなかった．また，ポンティック基 底面におおるプラークの付着は各観察時点で全く認めら れなかった（図5).

口腔生体㪟微鏡所見における毛細血管係蹄の形態の推 


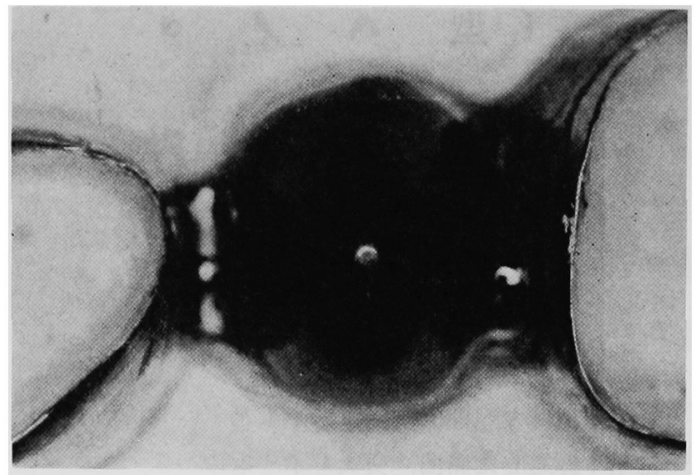

図 5 ポンティック基底面の規格写真

移を図 6 に示す. 橋義歯装着後 1 週目には I 型の割合が 減じ，交叉，屈曲を呈する II 型が $27 \%$ 認められた. 以 後, II 型の割合は 2 週目 $39 \%, 4$ 週目 $27 \%$ と変化なく 経過したが， 8 週目からは II 型が $46 \%$ と約半数を占め るようになり，12 週目に至ってもほぼ同様の傾向がみら れた（図 7,8）。

染色上皮所見では, 橋義歯装着後 1 週目ではコントロ ールとほぼ同様な所見を呈したが，2 週目になると染色 される上皮細胞数が増加し, 細胞閒境界が規則的に配列 した多角形を呈する上皮細胞が観察されるようになった (図 9).その染色態度はコントロールと同様淡染し, 上皮細胞の核は不明膫であった。この所見は各観察期間 を通して認められ, 12 週目に至るまで変化がなく経過し た (図 10).

\section{3. 圧迫型ポンティック}

圧迫型辸ティック下の歯槽堤粘膜は, 色調, 表面性 状に関してはコントロールに一致した所見を呈したが, 1 週目からポンティック基底面に一致した圧痕が形成さ れ，観察期間を通して同様に認められた. ポンティック 基底面に扔けるプラークの付着は非圧迫型と同様, 観察 期間中認められなかった.

口腔生体䫓微鏡所見における毛細血管保蹄の形態の推 移を図 11 亿示す. 橋義歯を装着後 1 2 週目ではП 型の 割合が $60 \%$ に增加するとともに，わずかではあるが連 続した交叉, 届曲を呈する而型が認められ, 非圧迫型に 比較し著明な血管形態の変化を示した (図 12).このIII 型は観察期間の経過に伴い増加の傾向にあり，4週目で は $15 \%, 8$ 週目では $27 \%$ の割合を占め, 12 週目に至る とそれ以上の変化はみられなくなった（図 13，14）.

また，染色上皮所見では 2 週目まではコントロールと ほぼ同様に経過したが，4 週目から染色される上皮細胞
29 巻 5 号 (1985)

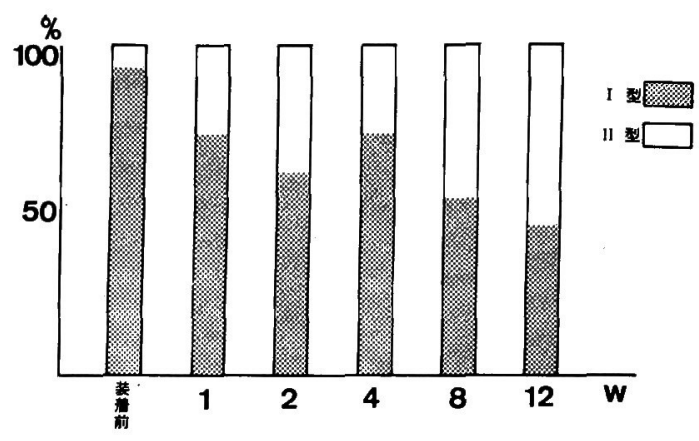

図 6 毛細血管係蹄形態の推移（非圧迫型）

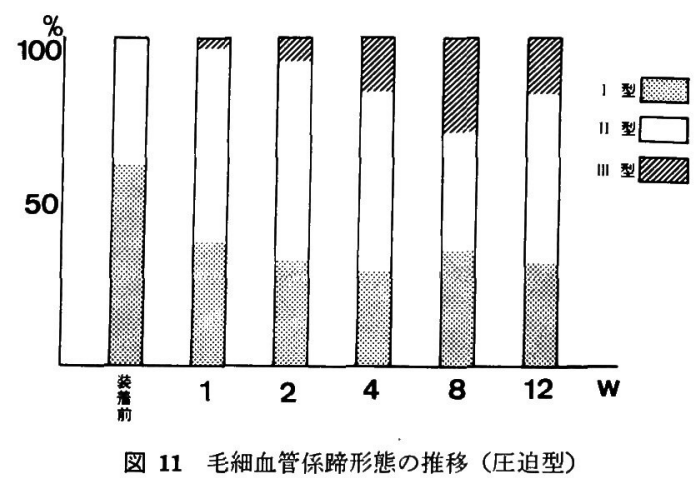

数が増加し，境界明瞭で規則的に配列した多角形を呈す る上皮細胞像が観察されるようになった（図 15，16）.

さらに, 8〜12 週目にかけては細胞間隙が明膫となり， 上皮細胞には漂染した核が認められるようになった（図 17).

\section{IV. 考察}

固定性橋義歯が周囲組織に生物学的為害作用を及ぼす ことなく, 可能な限り永く機能を維持するためには, ポ ンティックの設定による周囲組織の環境の変化にいかに 対応させるかが課題であった. 特に, ポンティック基底 面に付着するプラークの周囲組織に及ぼす影響が重要視 され, 基底面の材料的, 形態的問題が歯槽堤粘膜の炎症 性変化との関連で検討されてきた ${ }^{4 \sim 6)}$. その結 果, 艶焼 きされた陶材を用い，粘膜を軽く圧迫したリジラップ型 ポンティック，あるいは粘膜と無圧で接触させた楕円型 ポンティックが基底面に付着するプラークの影響から歯 槽堤粘膜を護る形態として考えられてきた。

しかし，いずれの形態を設定しても，粘膜に接触ある いは近接する領城にはプラークの付着が認められ，歯肉 
および歯槽堤粘膜と調和した橋義苗ポンティックを確立 するためには，いくつかの課題が残されていた. そこで 当教室芯は臨床的観察 ${ }^{2,8)}$, 実験的研究3)によりその解明 を試みてきた．橋義歯撤去症例を通してポンティック下 粘膜の組織反応を口腔生体顕微鏡的に観察してみると, 粘膜を軽く圧迫して製作されたリジラップ型ポンティッ クにおいても，軽度な炎症性変化が認められた8)。これ は，粘膜を軽く圧迫してもポンティック基底面の接触域 と非接触域の境界付近にはプラークが付着し，その影響 が歯槽堤粘膜に及んだ結果と考えられた．そこで，当教 室の古川ら ${ }^{3}$ は， ポンティック基底面が粘膜と接触する ごく狭い範囲を接触域と近接域に分け，プラークの付着 とその除去の観点から検討を加えた. その結果, 無圧で 接触させたものは軽く圧迫を加えたものより接触域，近 接域に付着するプラークの量が少なく, 軽く圧迫するこ とが粘膜の健康維持に特に有効とは考えにくいことを示 唆し, 圧迫型ポンティックの問題点を指摘した.

今回の観察に使用した口腔生体顕微鏡 M-100 型は口 腔粘膜の経時的変化を追求するため, 組織に侵襲を加え ることなく，同一部位を組織学的に観察する方法として 開発されたものである ${ }^{8)}$ 。この方法を用いれば，粘膜上 皮の表層における組織的変化および上皮下血管の変化を 観察することにより，補緅物の口腔粘膜に及ぼす影響を 客観的に判定できる. その組織的評価法については清野 の報告2)にもとづいた。

肉眼的所見ては，圧迫型に扔いて圧痕が形成された以 外，圧迫型と非圧迫型との差は認められなかったが，口 腔生体顕微鏡的には両者に明らかな違いが生じた、上皮 下血管所見をみると，圧迫型では毛細血管倸蹄頂が拡張 するとともに，交叉，屈曲が連続して現れ，非圧迫型に 比較してより複雑な形態変化を示した. このことは，上 皮下結合組織における炎症性変化がより強く惹起された ことを示している．染色上皮所見では非圧迫型が観察期 間を通して変化なく経過したのに対して，圧迫型では上 皮細胞の染色態度の変化および核の濃染として現れた. 圧迫型ポンティックを装着することによりポンティック 下粘膜の角化傾向が弱まることを示している.

本研究で設定した $0.3 \mathrm{~mm}$ の圧迫程度は, 装着時にポ ンティック基底面の周囲粘膜が貧血状態に宿らない程度 であるといわれている ${ }^{9)}$ ．実際，圧迫型橋義歯の装着時 には，周囲の粘膜に貧血状態が認められなかった．しか し，口腔生体顕微鏡所見をみると， 1 週目から上皮下血 管に変化が生し，毛細血管係蹄が交叉，屈曲を呈するも のが増加した. このことは, 肉眼的には貧血状態を示す
圧迫程度ではなかったにしても，圧迫により粘膜が変形 し，何らかの血液循環障害の影響があったものと考えら れる.このような粘膜の変形が長期間にわたって持続し た結果, 循環障害が増悪し, 複雑な形態を呈するIII型が 出現，增加したものと考えられる。

本研究で用いたポンティック形態は楕円型であり, 無 圧接触の場合は粘膜と点状に接する. したがって, 自浄 作用に優れるに加え，デンタルフロスの使用により基底 面は常に清潔な状態を保つことができた.このような環 境では, 生理的な刺激により粘膜上皮のもつ生体保護機 能が働き，上皮組織は健康な状態に維持できるものと考 えられる.これに対し, 圧迫型の場合は粘膜と接する範 囲が增大する. ポンティック基底面はデンタルフロスの 作用で清潔に維持できたが，ポンティックと接した粘膜 には生理的刺激が加わりにくく，正常な上皮組織構造と しての特徴が失われる.すなわち，生体保護機能の低下 により，上皮表層において角化の弱い細胞が出現し，口 腔生体顕微鏡的に上皮細胞の核の濃染として現れた．圧 迫型ポンティック基底面の近接域は非圧迫型ポンティッ クのそれより広く，付着するプラークの量が多いと報告 されている31. したがって, 本研究で得られた結果に加 え,プラークの影響が䡃けばポンティック下粘膜にはさ らに強い組織反応が惹起されることになろう．以上のよ らに, 圧迫型ポンティック下の粘膜には, 非圧迫型に比 較して,より強い組織反応が惹起されることが口腔生体 顕微鏡所見から明らかとなった.

\section{V. 結 論}

粘膜接触型ポンティックの接触条件の違いがポンティ ック下粘膜に及ぼす影響を口腔生体顕微鏡的に検討し, 次の結論を得た.

1. 橋義歯を装着することによりポンティック下粘膜 には接触条件のいかんにかかわりなく組織反応が惹起さ れた.

2. その組織反応は肉眼的にはとらえることはできな かったが, 口腔生体䫓微鏡的には上皮下血管の拡張と形 態の複雑化, 上皮細胞, 核の染色性の変化としてとらえ られた。

3. 口腔生体䫓微鏡的には非圧迫型より圧迫型の方が 強い組織反応を示した.

4. これらの組織反応はポンティック下粘膜の環境の 変化および圧迫による機械的刺激が関与したためと考え られた。 
178-1154 補緅誌 29 巻 5 号 (1985)

本論文の要旨は昭和 58 年第 70 回日本補緅歯科学会学術大会 で発表した.

\section{文献}

1）石橋寛二：歯肉および歯槽堤粘膜の炎症性変化に関する研 究一口腔生体顕微鏡による観 察一, 補 緅 誌, $22: 407$ $431,1978$.

2）清野和夫：橋義歯ポンティック下粘膜の病変の推移一口腔 生体顕微鏡による観察一, 岩手医誌,35:179 204,1983.

3）古川良俊, 水野富夫, 清野和夫, 塩山 司, 藤田 亮, 石 橋寛二, 高橋義和 : 橋義歯ポンティック基底面における歯 垢付着について一歯槽堤粘膜との接触様相からみた検 討一, 補緅誌, $28: 630 \sim 637,1983$.

4）石原寿郎, 田端恒雄, 長谷川成男: ダミー（その2）鞍状 ダミーの為害作用について, 歯界展望, $21: 496 \sim 502$,
1963.

5）石原寿郎, 吉田恵夫, 田端恒雄 : ダミー（その 3) ダミー の自浄性について, 歯界展望, $21: 1075 \sim 1084,1963$.

6) Stein, R.S. : Pontic-residual ridge relationship ; A reserch report. J. Prosthet. Dent., $16: 251 \sim 285,1966$.

7）石橋寛二, 深沢太賀男, 塩山司, 清野和夫, 石毛清雄, 石井秀明, 古川良俊 : 橋義歯ポンティック下粘膜の炎症性 変化に関寸る研究第 1 報臨床的観察, 補緅誌, 26 : $1146 \sim 1153,1982$.

8）石橋宽二, 清野和夫, 塩山 司, 水野富夫, 古川良俊 : 橋 義菌ポンティック下粘膜の炎症性変化に関寸る研究 第 2 報口腔生体顕微鏡による観察, 補緅誌, $26: 1154 \sim 1163$, 1982.

9）井上昌幸：ブリッジの診断から装着までー5・完一, 補緅 臨床, $9: 251 \sim 268,1977$. 


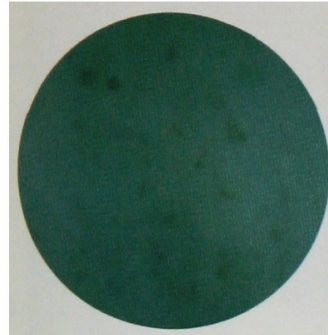

図 3 コントロールの上皮 下血管所見

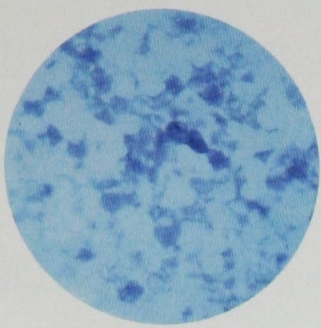

図 4 コントロールの染色 上皮所見

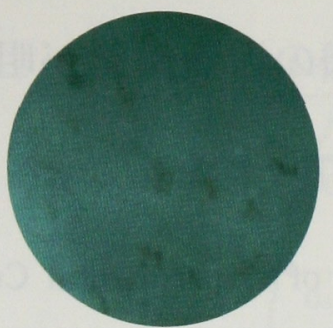

图 7 非圧迫型 4 週目の 上皮下血管所見

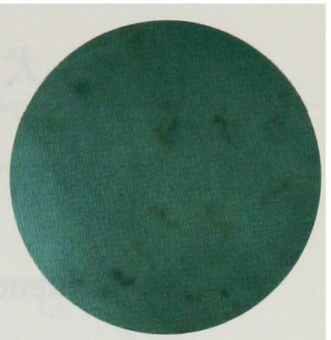

図 8 非圧迫型 12 週目の 上皮下血管所見

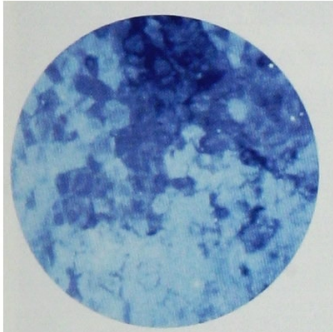

図 9 非圧迫型 2 週目の 染色上皮所見

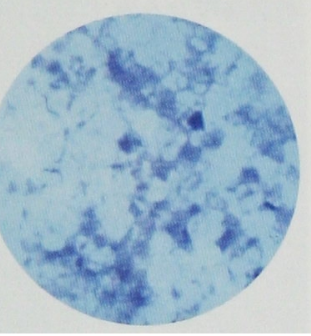

図 10 非圧迫型 12 週目 の染色上皮所見

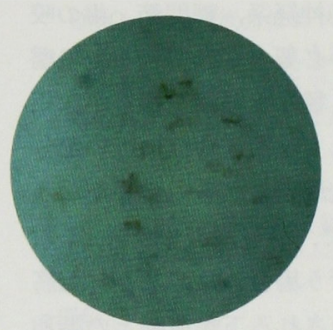

图 12 圧迫型 2 週目の上 皮下血管所見

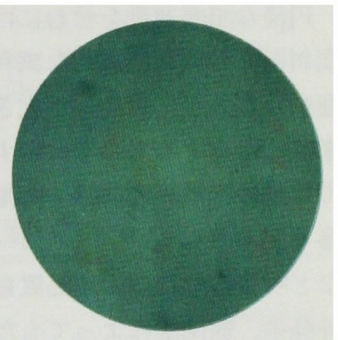

図 13 圧迫型 4 週目の上 皮下血管所見

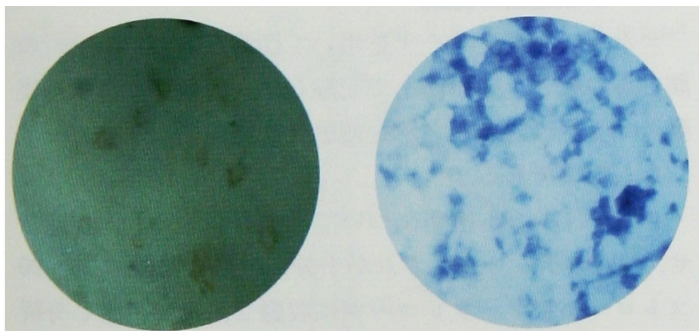

図 14 圧迫型 8 週目の上 皮下血管所見
図 15 圧迫型 2 週目の染 色上皮所見

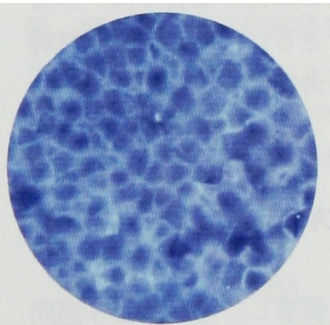

图 16 圧迫型 4 週目の染 色上皮所見

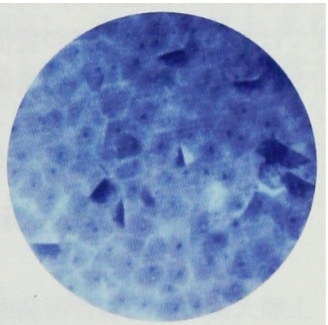

図 17 圧迫型 8 週目の染 色上皮所見 